\title{
Conformational Analysis for Hydrated Ethylene Imine Oligomer Models by Quantum Chemical Calculations
}

\author{
By Minoru KOBAYASHI, ${ }^{1, *}$ Makoto TAKAHASHI, ${ }^{1}$ and Hisaya SATO $^{2}$
}

\begin{abstract}
Hydrate effects on the conformations of ethylene imine oligomers (EI-x, $x=1-8$ mers) were examined using quantum chemical calculations. Models were constructed by locating a water molecule to each nitrogen atom in the structures optimized for non-hydrate oligomers. Hydrate ratio, $h\left(h=\mathrm{H}_{2} \mathrm{O}_{\mathrm{mol}} / \mathrm{N}_{\mathrm{mol}}\right)$, was set from 0 to 1 . Six type conformations with repeated units of $\mathrm{N}-\mathrm{C}, \mathrm{C}-\mathrm{C}$ and $\mathrm{C}-\mathrm{N}$ bonds were examined. Conformational energies $\left(E_{\mathrm{c}}\right)$ were calculated as differences between energies of oligomers with water molecules and those of non-hydrogen and/or hydrogen bonding water molecules. Hydrate energies for each conformer $\left(\Delta \mu_{\mathrm{h}}\right.$, based on $E_{\mathrm{c}}$ in non-hydrate state) were negative and linearly decreased with increase of $\mathrm{h}$, and all conformers were stabilized by electrostatic effect with hydration. $\mathrm{All}\left(\operatorname{tg}^{+} \mathrm{t}\right)_{\mathrm{x}}$ conformers with $\mathrm{h}<1$, and the $(\mathrm{ttt})_{\mathrm{x}}$ conformers over 3 mers with $\mathrm{h}=1$, were the most stable. Each result corresponded to results observed for nonhydrated and hydrated linear PEI crystals, respectively, and seemed to be related with hydrogen bonding between water molecules. Lengths of conformers having gauche structure significantly decreased with increasing h. Such contractions by hydrations, however, were independent of gauche preference energy $\left(\Delta E_{\mathrm{c}(\mathrm{g})}\right)$ of each conformer.

KEY WORDS: Conformation / Poly(ethylene imine) / Oligomer / Hydrate Effect / Quantum Chemical Calculation /
\end{abstract}

Poly(ethylene imine) (PEI) has unique properties because it possesses electron-releasing heteroatom $(\mathrm{N})$ in the skeletal chain, similar to heteroatom $(\mathrm{O})$ in poly(ethylene oxide) (PEO). Such properties, including specific affinity to substrate and solubility of inorganic salt, have been employed in the advancement of solid polymer electrolytes, ${ }^{1}$ gene delivery polymers, ${ }^{2}$ etc. These properties are often affected by conformational characteristics such as trans/gauche preferences, which depend on environmental factors such as temperature, solvent, etc. The conformational analyses of these polymers, therefore, are essential in the molecular design towards various applications.

X-Ray diffraction $(\mathrm{XRD})^{3-5}$ and other analyses ${ }^{6}$ have confirmed that the structure of a linear non-hydrated PEI crystal is a 5/1 double stranded helix, with a repeating tgt conformation for the $\mathrm{N}-\mathrm{C}, \mathrm{C}-\mathrm{C}$, and $\mathrm{C}-\mathrm{N}$ bonds. In the hydrate state, the structure transforms to the planar zigzag $\mathrm{ttt}$ conformation. Unlike the PEO solutions, the trans-fractions of the C-C bonds of the PEI solutions increase with increase of permittivity $(\varepsilon)$ of solvents, based on NMR analyses of $N, N^{\prime}$ dimethylethylenediamine (di-MEDA) as a model of PEI. ${ }^{7}$ The conformation of PEI, in this manner, specifically depends on environmental factors. Unfortunately, detailed understandings of these environmental effects have yet to be clarified because of the complexity in these effects.

To complement the experimental observations in the conformational analyses of PEO or PEI, computational chemistry is employed. Pioneering works on PEO, involving a rotational isomeric state model (RIS), was reported by Mark et al. ${ }^{8,9}$ More recently, studies of PEO and PEI using molecular mechanics (MM) and molecular dynamics (MD) have been reported. ${ }^{10-12}$ Furthermore, in contrast to the RIS, MM, and MD methods, recent studies involve quantum chemical calculations method (QCC). Although conformational analysis in the gaseous phase using QCC has been reported for dimethoxyethane (DME) $)^{13-16}$ and its oligomers ${ }^{13,17}$ (as models of PEO) and for di-MEDA ${ }^{7,18}$ (as a model of PEI), comparable studies in the liquid phase, however, are little. Smith et al. ${ }^{19}$ have reported the potential study of DME in aqueous solution (hydrate model) using QCC. The QCC studies on PEI in aqueous solution have yet to be reported.

We have reported the conformational analyses of EI oligomers, as a model of PEI, in the gaseous ${ }^{20}$ and liquid phase $^{21}$ using QCC. In the case of liquid phases, ${ }^{21}$ the conformational energies of 1- 4-mers were estimated by IPCM method ${ }^{22}$ using the permittivity: $\varepsilon(\varepsilon=0-80.1$ : water) of solvents, and the results were in good agreement with those obtained by NMR analysis. In this paper, in order to estimate in more detail with the conformations in hydrate state, the hydrate models for EI oligomers (1- 8-mers) were investigated. The energies and structures optimized for these hydrate models were examined using QCC, and the conformational characteristics of hydrated EI oligomers were discussed.

\section{QUANTUM CHEMICAL CALCULATIONS (QCC)}

\section{Designations of Non-Hydrate Oligomer Models (EI-x)}

EI $\mathrm{x}$-mers ( $\mathrm{x}=1-8$ monomer units) capped with $\mathrm{N}$ methylimino and methyl groups were used for the oligomer models (single chain) of PEI. The specified structures are given in Table I. The structural example designated for EI-1 is given in Figure 1. For each oligomer, the conformation $\left(\tau_{\mathrm{n}} \tau_{\mathrm{n}+1} \tau_{\mathrm{n}+2}\right)_{\mathrm{x}}$

\footnotetext{
${ }^{1}$ Graduate School of Bio-Applications and Systems Engineering, Tokyo University of Agriculture and Technology, Naka-cho, Koganei 184-8588, Japan ${ }^{2}$ Graduate School of Technical Management, Tokyo University of Agriculture and Technology, Naka-cho, Koganei 184-8588, Japan

*To whom correspondence should be addressed (Tel: +81-72-689-1918, Fax: +81-72-689-1918, E-mail: mikoba3@aol.com).
} 
Table I. Non-hydrate models

\begin{tabular}{cclr}
\hline No. & $\begin{array}{c}\text { Monomer unit } \\
\text { number: } x\end{array}$ & \multicolumn{1}{c}{ Molecular models } & $\begin{array}{c}\text { Molecular } \\
\text { weights }\end{array}$ \\
\hline $\mathrm{El}-1$ & 1 & $\mathrm{CH}_{3} \mathrm{NH}-\left(\mathrm{CH}_{2} \mathrm{CH}_{2} \mathrm{NH}\right)_{1}-\mathrm{CH}_{3}{ }^{\mathrm{a}}$ & 88.18 \\
$\mathrm{El}-2$ & 2 & $\mathrm{CH}_{3} \mathrm{NH}-\left(\mathrm{CH}_{2} \mathrm{CH}_{2} \mathrm{NH}\right)_{2}-\mathrm{CH}_{3}$ & 131.26 \\
$\mathrm{El}-3$ & 3 & $\mathrm{CH}_{3} \mathrm{NH}-\left(\mathrm{CH}_{2} \mathrm{CH}_{2} \mathrm{NH}\right)_{3}-\mathrm{CH}_{3}$ & 174.34 \\
$\mathrm{El}-4$ & 4 & $\mathrm{CH}_{3} \mathrm{NH}-\left(\mathrm{CH}_{2} \mathrm{CH}_{2} \mathrm{NH}\right)_{4}-\mathrm{CH}_{3}$ & 217.42 \\
$\mathrm{El}-5$ & 5 & $\mathrm{CH}_{3} \mathrm{NH}-\left(\mathrm{CH}_{2} \mathrm{CH}_{2} \mathrm{NH}\right)_{5}-\mathrm{CH}_{3}$ & 260.50 \\
$\mathrm{El}-8$ & 8 & $\mathrm{CH}_{3} \mathrm{NH}-\left(\mathrm{CH}_{2} \mathrm{CH}_{2} \mathrm{NH}\right)_{8}-\mathrm{CH}_{3}$ & 389.74 \\
\hline
\end{tabular}

a $N, N^{\prime}$-Dimethylethylenediamine (di-MEDA).

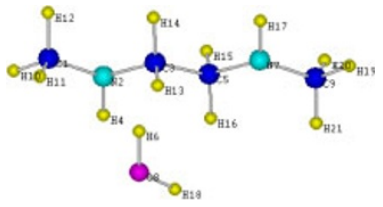

Designated $\mathrm{d}_{\mathrm{N} \cdot \mathrm{H}}(\AA)=1.70(\mathrm{~N} 2 \cdots \mathrm{H} 6)$ $\mathrm{d}_{\mathrm{N}-\mathrm{O}}(\AA)=2.66(\mathrm{~N} 2 \cdots \mathrm{O} 8)$

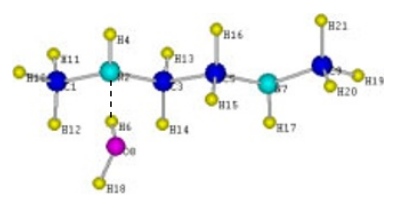

Optimized

$\mathrm{d}_{\mathrm{N} \cdot \mathrm{H}}(\AA)=1.96(\mathrm{~N} 2 \cdots \mathrm{H} 6)$ $\mathrm{d}_{\mathrm{N}-\mathrm{O}}(\AA)=2.93(\mathrm{~N} 2 \cdots \mathrm{O} 8)$
Figure 1. The designated and optimized structures for the hydrated conformer of El-1 (conformation: (ttt) $)_{1}, \mathrm{~h}=0.5, \cdots$ : hydrogen bond). Conformation was defined by $\left(\tau_{n} \tau_{n+1} \tau_{n+2}\right)_{x}$, where $\tau_{n}, \tau_{n+1}$, and $\tau_{\mathrm{n}+2}$ are the dihedral angles $\left({ }^{\circ}\right)$ for $\mathrm{N}-\mathrm{C}, \mathrm{C}-\mathrm{C}$, and $\mathrm{C}-\mathrm{N}$ bonds, respectively, and $\mathrm{x}$ is monomer unit number. In "Dseignated" of the figure, the values of $-175^{\circ},-175^{\circ}$, and $180^{\circ}$ as the dihedral angles were used for $\mathrm{N} 2-\mathrm{C} 3, \mathrm{C} 3-\mathrm{C} 5$, and $\mathrm{C} 5-\mathrm{N} 7$ bonds, respectively. Hydrate distance: $d_{N-H}(\AA)$ was defined for the hydrogen bonding of $\mathrm{N} . . . \mathrm{HOH}^{\prime}(\mathrm{N} 2 \ldots \mathrm{H} 6)$ as shown in "Optimized" in the figure.

( $\tau$ : dihedral angles, $\mathrm{n}$ : sequential number of atoms along a skeletal chain) are designated as $(t t t)_{x},\left(\operatorname{ttg}^{+}\right)_{x},\left(\operatorname{tg}^{+} t\right)_{x}$, $\left(\operatorname{tg}^{+} \mathrm{g}^{+}\right)_{\mathrm{x}},\left(\operatorname{tg}^{+} \mathrm{g}^{-}\right)_{\mathrm{x}}$, and $\left(\mathrm{g}^{+} \mathrm{g}^{+} \mathrm{g}^{+}\right)_{\mathrm{x}}\left(\mathrm{t}\right.$, trans; $\mathrm{g}^{+}$and $\mathrm{g}^{-}$, gauche) as the combination of $\tau$ that are repeated for the units of N-C, C-C, and C-N bonds. Every dihedral angle was independently assigned along the skeletal chains. As reported in our previous paper, ${ }^{20}$ both energies and pseudoasymmetries (racemo or meso, due to a nitrogen inversion) of EI conformers (1-11 mers) in gaseous phase opitimized using QCC (RHF/ $6-31+G(d, p))$ were affected by the designation values for the trans conformation. And all the most stable conformers, in which the pseudoasymmetries of $(\mathrm{ttt})_{\mathrm{x}}$ conformers were racemo, were obtained by using the designation values for the trans conformation as follow: $\tau_{\mathrm{n}} / \tau_{\mathrm{n}+1} / \tau_{\mathrm{n}+2}$ was $-175^{\circ} /-175^{\circ} / 180^{\circ}$ (partially restricted system). In this study, therefore, above designation system for trans values was used in designations of each dihedral angle. For the gauche value, $+60^{\circ}\left(\mathrm{g}^{+}\right)$and $-60^{\circ}$ $\left(\mathrm{g}^{-}\right)$were used.

\section{Designations of Hydrate Oligomer Models}

Hydrate models were prepared by adding water to the structure optimized for non-hydrate model. The optimizations of non-hydrate models were carried out firstly by RHF/STO$3 \mathrm{G}$, and then RHF/6-31G method which is the same method as used in optimizations of hydrate models; for more detail, refer following section. Each water molecule $\left(\mathrm{H}_{2} \mathrm{O}\right)$ was located to a nitrogen atom $(\mathrm{N})$. The specified models are given in Table II.
Table II. Hydrate models

\begin{tabular}{|c|c|c|c|c|}
\hline $\begin{array}{l}\text { Oligo- } \\
\text { mers }\end{array}$ & Hydrate models ${ }^{a}$ & $\begin{array}{l}\text { Number of } \\
\mathrm{N} \text { atom: } \mathrm{N}_{\mathrm{n}}\end{array}$ & $\begin{array}{l}\text { Number of } \\
\mathrm{H}_{2} \mathrm{O}: \mathrm{N}_{\mathrm{w}}\end{array}$ & $\begin{array}{l}\text { Hydrate ratio: } \\
\qquad \mathrm{h}\left(\mathrm{N}_{\mathrm{w}} / \mathrm{N}_{\mathrm{n}}\right)\end{array}$ \\
\hline \multirow[t]{2}{*}{$\mathrm{El}-1$} & $\underline{\mathrm{N}}-\mathrm{N}$ & 2 & 1 & 0.500 \\
\hline & $\underline{N}-\underline{N}$ & 2 & 2 & 1.000 \\
\hline \multirow[t]{3}{*}{$\mathrm{El}-2$} & $\mathrm{~N}-\underline{\mathrm{N}}-\mathrm{N}$ & 3 & 1 & 0.333 \\
\hline & $\underline{N}-\mathrm{N}-\underline{N}$ & 3 & 2 & 0.667 \\
\hline & $\underline{N}-\underline{N}-\underline{N}$ & 3 & 3 & 1.000 \\
\hline \multirow[t]{2}{*}{ El-3 } & $\underline{\mathrm{N}}-\mathrm{N}-\underline{\mathrm{N}}-\mathrm{N}$ & 4 & 2 & 0.500 \\
\hline & $\underline{\mathrm{N}}-\underline{\mathrm{N}}-\underline{\mathrm{N}}-\underline{\mathrm{N}}$ & 4 & 4 & 1.000 \\
\hline \multirow[t]{3}{*}{$\mathrm{El}-4$} & $\mathrm{~N}-\underline{\mathrm{N}}-\mathrm{N}-\underline{\mathrm{N}}-\mathrm{N}$ & 5 & 2 & 0.400 \\
\hline & $\underline{\mathrm{N}}-\mathrm{N}-\underline{\mathrm{N}}-\mathrm{N}-\underline{\mathrm{N}}$ & 5 & 3 & 0.600 \\
\hline & $\underline{\mathrm{N}}-\underline{\mathrm{N}}-\underline{\mathrm{N}}-\underline{\mathrm{N}}-\underline{\mathrm{N}}$ & 5 & 5 & 1.000 \\
\hline \multirow[t]{2}{*}{$\mathrm{El}-5$} & $\underline{\mathrm{N}}-\mathrm{N}-\underline{\mathrm{N}}-\mathrm{N}-\underline{\mathrm{N}}-\mathrm{N}$ & 6 & 3 & 0.500 \\
\hline & $\underline{\mathrm{N}}-\underline{\mathrm{N}}-\underline{\mathrm{N}}-\underline{\mathrm{N}}-\underline{\mathrm{N}}-\underline{\mathrm{N}}$ & 6 & 6 & 1.000 \\
\hline \multirow[t]{2}{*}{$\mathrm{El}-8$} & $\mathrm{~N}-\underline{\mathrm{N}}-\mathrm{N}-\underline{\mathrm{N}}-\mathrm{N}-\underline{\mathrm{N}}-\mathrm{N}-\underline{\mathrm{N}}-\mathrm{N}$ & 9 & 4 & 0.444 \\
\hline & $\underline{\mathrm{N}}-\underline{\mathrm{N}}-\underline{\mathrm{N}}-\underline{\mathrm{N}}-\underline{\mathrm{N}}-\underline{\mathrm{N}}-\underline{\mathrm{N}}-\underline{\mathrm{N}}-\underline{\mathrm{N}}$ & 9 & 9 & 1.000 \\
\hline
\end{tabular}

${ }^{\text {a }} \mathrm{N}$ and $\underline{\mathrm{N}}$ show non-hydrated and hydrayted units, respectively. $(\mathrm{N}, \underline{\mathrm{N}}$ : $\mathrm{RNHR}, \mathrm{R}, \mathrm{R}^{\prime}=\mathrm{CH}_{3}$ or $\mathrm{CH}_{2} \mathrm{CH}_{2}$ )

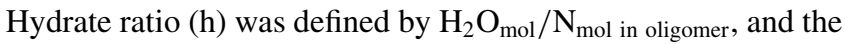
values of $0-1$ were used. The structural example $(\mathrm{h}=0.5)$ designated for EI-1 is given in Figure 1. Hydrate distance: $d_{N-H}$

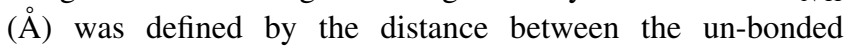
nitrogen atom and hydrogen atom $(\mathrm{H})$ in water molecule $\left(\mathrm{HOH}^{\prime}\right)$, in which $\mathrm{H}$ atom is closer to the un-bonded nitrogen than $\mathrm{H}^{\prime}$ atom as shown in Figure 1 . The value of $1.7 \AA$ was used as $\mathrm{d}_{\mathrm{N}-\mathrm{H}}$, except for otherwise noted.

\section{Conformational Analyses}

Conformational analyses were carried out for each model using QCC via the Gaussian 03W (Gaussian Inc.) program. ${ }^{23}$ For structural optimizations, RHF/6-31G was used as the calculation method. The structural energies of hydrated oligomers with waters, $E_{\mathrm{h}}$ (Hartree, 1 Hartree $=627.51 \mathrm{kcal} /$ mol) were calculated for the optimized structures. The conformational energies for oligomer structures in hydrated oligomers, $E_{\mathrm{c}}$, were calculated via eqs (1) and (2).

$$
\begin{aligned}
E_{\mathrm{c}} & =E_{\mathrm{h}}-\sum E_{\mathrm{w}} \\
\sum E_{\mathrm{w}} & =E_{\mathrm{w}(\mathrm{n})}+E_{\mathrm{w}(\mathrm{h})}
\end{aligned}
$$

where $\sum E_{\mathrm{w}}$ is the total energy of the hydrating water molecules. $E_{\mathrm{w}(\mathrm{n})}$ and $E_{\mathrm{w}(\mathrm{h})}$ are the energies of non-hydrogen and hydrogen bonded water molecules, respectively. The formation of hydrogen bond between water molecules was confirmed by the $\mathrm{O} \cdots \mathrm{O}$ distance $\left(\mathrm{D}_{\mathrm{O}-\mathrm{O}}\right)$ between water molecules neighboring an imino group, which were estimated in the optimized structures. The $\mathrm{D}_{\mathrm{O}-\mathrm{O}}$ values in non-hydrogen and hydrogen bonded water molecules were defined as longer value than $3 \AA$ and shorter value than $3 \AA$, respectively, according to the results observed for water dimer ( $\mathrm{D}_{\mathrm{O}-\mathrm{O}}: 2.74 \AA$ in regular ice, ${ }^{24} 2.85 \AA$ in liquid, ${ }^{24}$ and $2.98 \AA$ in vapor $^{25,26}$ ). The $E_{\mathrm{w}(\mathrm{n})}$ and $E_{\mathrm{w}(\mathrm{h})}$ were estimated using the models for nonhydrogen (single molecule) and hydrogen (some molecules located linearly) bonded water molecules having some units number, respectively, by $\mathrm{RHF} / 6-31 \mathrm{G}$. The $\mathrm{D}_{\mathrm{O}-\mathrm{O}}$ values for hydrogen bonded water molecules in the optimized structures 
Table III. Energies $\left(E_{\mathrm{w}}, \mathrm{HF}\right)$ calculated for water molecules by $\mathrm{RHF} / 6-31 \mathrm{G}$

\begin{tabular}{|c|c|c|c|c|c|c|c|c|}
\hline $\mathrm{n}^{\mathrm{a}}$ & $E_{\mathrm{w}(\mathrm{n})}^{\mathrm{b}}$ & $E_{\mathrm{w}(\mathrm{h})}^{\mathrm{c}}$ & $\mathrm{n}^{\mathrm{a}}$ & $E_{\mathrm{w}(\mathrm{n})}^{\mathrm{b}}$ & $E_{\mathrm{w}(\mathrm{h})}{ }^{\mathrm{c}}$ & $\mathrm{n}^{\mathrm{a}}$ & $E_{\mathrm{w}(\mathrm{n})}^{\mathrm{b}}$ & $E_{\mathrm{w}(\mathrm{h})}{ }^{\mathrm{c}}$ \\
\hline 1 & -75.9854 & & 4 & -303.9416 & -303.9850 & 7 & -531.8978 & -531.9939 \\
\hline 2 & -151.9708 & -151.9826 & 5 & -379.9274 & -379.9876 & 8 & -607.8832 & -607.9973 \\
\hline 3 & -227.9562 & -227.9830 & 6 & -455.9128 & -455.9907 & 9 & -683.8686 & -684.0007 \\
\hline
\end{tabular}

aUnits number of water molecules. ${ }^{b}$ Energies of non-hydrogen bonded water molecules. ${ }^{c}$ Energies for linear hydrogen bonded structures which are consisted of $n$ units of sequential water molecules $\left(D_{O-O}=2.71-2.85 \AA\right)$.

were shorter than $3 \AA$ (2.71-2.85 The $E_{\mathrm{w}(\mathrm{n})}$ and $E_{\mathrm{w}(\mathrm{h})}$ values are given in Table III. The conformations were specified based on IUPAC ${ }^{27}$ as follow: $\tau_{\mathrm{n}}$ of trans $\left(\mathrm{t}^{ \pm}\right)$and gauche $\left(\mathrm{g}^{ \pm}\right)$are $\pm 120^{\circ}$ to $\pm 180^{\circ}$ and $\pm 0^{\circ}$ to $\pm 120^{\circ}$, respectively. Lengths of oligomer molecules were defined by $\mathrm{L}(\AA)$, where $\mathrm{L}$ is un-bonded distance between the terminal nitrogen atoms. In Figure, for example, $\mathrm{L}$ is given as that between $\mathrm{N} 2$ and $\mathrm{N} 7$.

\section{RESULTS AND DISCUSSION}

\section{Effects of Designations on the Optimized Structures}

The influences of the designated hydrate distance on the optimized structures were examined using EI 1-mer models (EI-1). The structural optimizations were carried out using the RHF/6-31G method with structures that were optimized in each non-hydrate model.

Firstly, the hydrate models with $\mathrm{h}=0.5$ (having one molecule of water) were examined. The results are shown in Table IV. The structure optimized for $(\mathrm{ttt})_{1}$ conformer is shown in Figure 1. As shown in Table IV and Figure 1, the optimized

\begin{tabular}{|c|c|c|c|c|c|}
\hline \multirow{2}{*}{$\begin{array}{l}\text { Confor- } \\
\text { mations }\end{array}$} & \multicolumn{2}{|c|}{ Designated } & \multicolumn{2}{|c|}{ Optimized } & \multirow[b]{2}{*}{$E_{\mathrm{c}}(\mathrm{HF})$} \\
\hline & $d_{N 1-H^{a}}$ & $d_{N 1-O}{ }^{a}$ & $\mathrm{~d}_{\mathrm{N} 1-\mathrm{H}^{\mathrm{a}}}$ & $\mathrm{d}_{\mathrm{N} 1-\mathrm{O}}{ }^{\mathrm{a}}$ & \\
\hline \multirow[t]{3}{*}{$(\mathrm{ttt})_{1}$} & 1.70 & 2.66 & 1.96 & 2.93 & -267.2173 \\
\hline & 1.80 & 2.47 & 1.96 & 2.93 & -267.2173 \\
\hline & 2.20 & 2.85 & 1.96 & 2.93 & -267.2173 \\
\hline \multirow[t]{3}{*}{$\left(\operatorname{tg}^{+} t\right)_{1}$} & 1.70 & 2.66 & 1.90 & 2.85 & -267.2203 \\
\hline & 1.80 & 2.47 & 1.90 & 2.85 & -267.2203 \\
\hline & 2.20 & 2.85 & 1.90 & 2.85 & -267.2203 \\
\hline
\end{tabular}

a The $d_{\mathrm{N} 1-\mathrm{H}}$ and $\mathrm{d}_{\mathrm{N} 1-\mathrm{O}}$ values are the unbonding distances of $\mathrm{N} 1 \ldots \mathrm{H}$ (in water) and $\mathrm{N} 1 \ldots \mathrm{O}$ (in water), respectively. hydrate distances: $\mathrm{d}_{\mathrm{N}-\mathrm{H}}$ and $\mathrm{d}_{\mathrm{N}-\mathrm{O}}\left(\mathrm{d}_{\mathrm{N}-\mathrm{O}}\right.$ : un-bonding distance between nitrogen and water's oxygen) were constant independent of designated $\mathrm{d}_{\mathrm{N}-\mathrm{H}}$ values $(1.7-2.2 \AA$ ) and conformations. According to the XRD for linear hydrated PEI crystal, the $\mathrm{d}_{\mathrm{N}-\mathrm{O}}$ values observed in the structure (all-trans) is $2.87-$ $3.05 \AA$ for hemi-hydrate $\left(0.5 \mathrm{~mol} \mathrm{H}_{2} \mathrm{O}\right.$ per monomer unit $) .{ }^{5}$ The $\mathrm{d}_{\mathrm{N} \text {-O }}$ value $(2.93 \AA)$ calculated for $(\mathrm{ttt})_{1}$ conformer fell within the observed values.

Secondly, the hydrate models with $\mathrm{h}=1$ (having two molecules of water) were examined. The results are shown in Table V. The structures optimized for $(t t t)_{1}$ and $\left(\operatorname{tg}^{+} t\right)_{1}$ conformers are shown in Figures 2 and 3, respectively. For sesqui-hydrate PEI (all-trans, $1.5 \mathrm{~mol}_{2} \mathrm{O}$ per monomer unit), the observed $\mathrm{d}_{\mathrm{N}-\mathrm{O}}$ values are $2.93-2.96 \AA^{3}$. As shown in Table V and Figure 2, the $\mathrm{d}_{\mathrm{N}-\mathrm{O}}(2.88 \AA)$ calculated for the $(\mathrm{ttt})_{1}$ conformer agreed with the $\mathrm{d}_{\mathrm{N}-\mathrm{O}}$ values observed, independent of designated $\mathrm{d}_{\mathrm{N}-\mathrm{H}}$ values. The structures of $\left(\mathrm{tg}^{+} \mathrm{t}\right)_{1}$ conformers were almost same independent of designated $\mathrm{d}_{\mathrm{N}-\mathrm{H}}$ values. The $E_{\mathrm{c}}$ values of $\left(\operatorname{tg}^{+} \mathrm{t}\right)_{1}$ conformers, however, were not same with the designated $d_{N-H}$ values, and the $\left(\operatorname{tg}^{+} t\right)_{1}$ conformer designated by $\mathrm{d}_{\mathrm{N}-\mathrm{H}}$ values of $1.7 \AA$ was the most stable. In the $\left(\operatorname{tg}^{+} \mathrm{t}\right)_{1}$ conformer designated by $\mathrm{d}_{\mathrm{N}-\mathrm{H}}$ values of $2.64 \AA$, the $E_{\mathrm{c}}$ value could not be estimated because of non-converged in its optimization.

Taking into account these results in $\mathrm{h}=0.5$ and 1 mentioned above, the value of $1.7 \AA$ as $\mathrm{d}_{\mathrm{N}-\mathrm{H}}$ value was used in all designations herein after.

\section{Hydrate Effects on the Energy of Each Conformer}

The conformational analyses for the hydrate EI oligomer models (EI-x, $x=1-8$ ) were carried out using the RHF/6-31G method with the structures optimized for non-hydrate models. The conformational energies, $E_{\mathrm{c}}$, were calculated via eqs (1) and (2). In Table VI, the examples of calculations for $E_{\mathrm{c}}$ (EI-1, conformation: $\left.(\mathrm{ttt})_{1}\right)$ are shown. For all models, the difference

Table V. Effects of designated hydrate distances on the structures optimized for the hydrates of $h=1$ (El-1: $\mathrm{CH}_{3}-\mathrm{N} 1 \mathrm{H}-\mathrm{CH}_{2} \mathrm{CH}_{2}-\mathrm{N} 2 \mathrm{H}-\mathrm{CH}_{3}$, Water: $\mathrm{H} 1 \mathrm{O} 1 \mathrm{H} 1, \mathrm{H} 2 \mathrm{O} 2 \mathrm{H} 2$, by $\mathrm{RHF} / 6-31 \mathrm{G}$ )

\begin{tabular}{|c|c|c|c|c|c|c|c|c|c|}
\hline \multirow{3}{*}{$\begin{array}{l}\text { Confor- } \\
\text { mations }\end{array}$} & \multicolumn{4}{|c|}{ Designated distances $(\AA ̊)$} & \multicolumn{2}{|c|}{ Optimized structures } & \multirow{2}{*}{\multicolumn{2}{|c|}{ Water-Water $(\AA)$}} & \multirow{3}{*}{$E_{\mathrm{c}}(\mathrm{HF})$} \\
\hline & \multicolumn{2}{|c|}{ Hydrate } & \multicolumn{2}{|c|}{ Water-Water } & Hydrate $(\AA ̊)$ & \multirow[b]{2}{*}{$\mathrm{d}_{\mathrm{N} 2-\mathrm{H} 2 / \mathrm{d}_{\mathrm{N} 2-\mathrm{O} 2}}$} & & & \\
\hline & $\mathrm{d}_{\mathrm{N}-\mathrm{H}}$ & $\mathrm{d}_{\mathrm{N}-\mathrm{O}}$ & $\mathrm{D}_{\mathrm{O} 1-\mathrm{H} 2}{ }^{\mathrm{a}}$ & $\mathrm{D}_{\mathrm{O} 1-\mathrm{O} 2}$ & $\mathrm{~d}_{\mathrm{N} 1-\mathrm{H} 1} / \mathrm{d}_{\mathrm{N} 1-\mathrm{O} 1}$ & & $\mathrm{D}_{\mathrm{O} 1-\mathrm{H} 2}{ }^{\mathrm{a}}$ & $\mathrm{D}_{\mathrm{O} 1-\mathrm{O} 2}$ & \\
\hline \multirow[t]{2}{*}{$(\mathrm{ttt})_{1}$} & 1.70 & 2.66 & 5.97 & 6.80 & $1.93 / 2.88$ & $1.93 / 2.88$ & 5.98 & 6.69 & -267.2320 \\
\hline & 2.20 & 2.85 & 5.87 & 6.80 & $1.93 / 2.88$ & $1.93 / 2.88$ & 5.98 & 6.69 & -267.2320 \\
\hline \multirow[t]{3}{*}{$\left(\operatorname{tg}^{+} t\right)_{1}$} & 1.70 & 2.66 & 3.29 & 4.04 & $1.88 / 2.84^{b}$ & $1.96 / 2.90^{c}$ & 2.58 & 3.12 & -267.2392 \\
\hline & 2.18 & 3.05 & 3.50 & 4.33 & $1.88 / 2.84^{b}$ & $1.96 / 2.90^{c}$ & 2.57 & 3.12 & -267.2387 \\
\hline & 2.64 & 3.48 & 3.78 & 4.67 & $-^{d}$ & $-^{d}$ & $-^{d}$ & $-^{d}$ & $-^{d}$ \\
\hline
\end{tabular}

a "H2" in "O1-H2" shows a hydrogen atom which is more neighboring to $\mathrm{O} 1$ atom. ${ }^{\mathrm{b}, \mathrm{c}}$ The values with "b" and "c" are those for $\mathrm{d}_{\mathrm{N} 1-\mathrm{H} 2} / \mathrm{d}_{\mathrm{N} 1-\mathrm{O} 2}$ and $\mathrm{d}_{\mathrm{N} 2-\mathrm{H} 1} / \mathrm{d}_{\mathrm{N2}-\mathrm{O} 1}$, respectively, because the water's location to a nitrogen atom transferred each other by optimization, refer Figure 3 . ${ }^{d}$ Non-converged in optimization. 

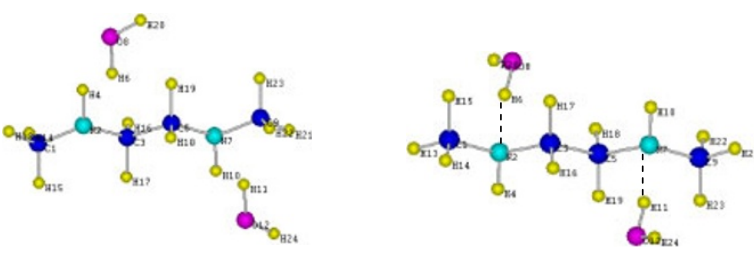

Designated

$\mathrm{d}_{\mathrm{N}-\mathrm{H}}(\AA)=1.70(\mathrm{~N} 2 \cdots \mathrm{H} 6, \mathrm{~N} 7 \cdots \mathrm{H} 11)$ $\mathrm{d}_{\mathrm{N}-\mathrm{O}}(\AA)=2.66(\mathrm{~N} 2 \cdots \mathrm{O} 8, \mathrm{~N} 7 \cdots \mathrm{O} 12)$ $\mathrm{D}_{\mathrm{O}-\mathrm{O}}(\AA)=6.80(\mathrm{O} 8 \cdots \mathrm{O} 12)$

$\rightarrow$ $\mathrm{d}_{\mathrm{N}-\mathrm{H}}(\AA)=1.93(\mathrm{~N} 2 \cdots \mathrm{H} 6), 1.93(\mathrm{~N} 7 \cdots \mathrm{H} 11)$ $\mathrm{d}_{\mathrm{N}-\mathrm{O}}(\AA)=2.88(\mathrm{~N} 2 \cdots \mathrm{O} 8), 2.88(\mathrm{~N} 7 \cdots \mathrm{O} 12)$ $\mathrm{D}_{\mathrm{O}-\mathrm{O}}(\AA)=6.69(\mathrm{O} 8 \cdots \mathrm{O} 12)$

Figure 2. The designated and optimized structures for the hydrated conformer of El-1 (conformation: (ttt) $)_{1}, \mathrm{~h}=1, \cdots$ : hydrogen bond).

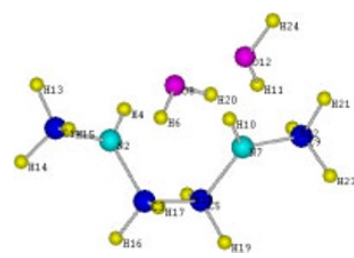

Designated

$\mathrm{d}_{\mathrm{N}-\mathrm{H}}(\AA)=1.70(\mathrm{~N} 2 \cdots \mathrm{H} 6, \mathrm{~N} 7 \cdots \mathrm{H} 11)$ $\mathrm{d}_{\mathrm{N}-\mathrm{O}}(\AA)=2.66(\mathrm{~N} 2 \cdots \mathrm{O} 8, \mathrm{~N} 7 \cdots \mathrm{O} 12)$ $\mathrm{D}_{\mathrm{O}-\mathrm{O}}(\AA)=4.04(\mathrm{O} 8 \cdots \mathrm{O} 12)$

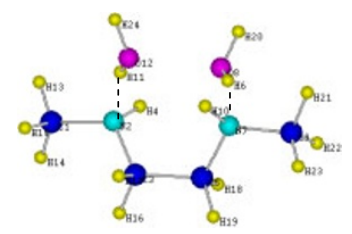

$\rightarrow$

Optimized

$\mathrm{d}_{\mathrm{N}-\mathrm{H}}(\AA)=1.88(\mathrm{~N} 2 \cdots \mathrm{H} 11), 1.96(\mathrm{~N} 7 \cdots \mathrm{H} 6)$ $\mathrm{d}_{\mathrm{N}-\mathrm{O}}(\AA)=2.84(\mathrm{~N} 2 \cdots \mathrm{O} 12), 2.90(\mathrm{~N} 7 \cdots \mathrm{O} 8)$ $\mathrm{D}_{\mathrm{O}-\mathrm{O}}(\AA)=3.12(\mathrm{O} 8 \cdots \mathrm{O} 12)$

Figure 3. The designated and optimized structures for the hydrated conformer of El-1 (conformation: $\left(\operatorname{tg}^{+} \mathrm{t}\right)_{1}, \mathrm{~h}=1, \cdots$ : hydrogen bond).

Table VI. Examples of calculations for conformational energy $\left(E_{\mathrm{c}}\right)$ (oligomer: El-1, conformation: (ttt) ${ }_{1}$, calculation: RHF/6-31G)

\begin{tabular}{|c|c|c|c|c|c|c|c|c|}
\hline \multirow{3}{*}{$\mathrm{h}$} & \multirow{3}{*}{$\mathrm{N}_{\mathrm{w}}$} & \multirow{3}{*}{$E_{\mathrm{h}}(\mathrm{HF})^{\mathrm{a}}$} & \multicolumn{5}{|c|}{ Water molecules } & \multirow{3}{*}{$\begin{array}{c}E_{\mathrm{c}}(\mathrm{HF}, \\
\left.E_{\mathrm{c}}=E_{\mathrm{h}}-\sum E_{\mathrm{w}}\right)\end{array}$} \\
\hline & & & \multicolumn{2}{|c|}{ Non H-bonded } & \multicolumn{2}{|c|}{ H-bonded } & \multirow{2}{*}{$\sum E_{\mathrm{w}}$} & \\
\hline & & & $\mathrm{N}_{\mathrm{w}(\mathrm{n})}{ }^{\mathrm{b}}$ & $E_{\mathrm{w}(\mathrm{n})}(\mathrm{HF})^{\mathrm{c}}$ & $\mathrm{N}_{\mathrm{w}(\mathrm{h})}{ }^{\mathrm{d}}$ & $E_{\mathrm{w}(\mathrm{h})}(\mathrm{HF})$ & & \\
\hline 0 & 0 & -267.2045 & 0 & 0 & 0 & 0 & 0 & -267.2045 \\
\hline 0.5 & 1 & -343.2027 & 1 & -75.9854 & 0 & 0 & -75.9854 & -267.2173 \\
\hline 1 & 2 & -419.2028 & 2 & -151.9708 & 0 & 0 & -151.9708 & -267.2320 \\
\hline
\end{tabular}

${ }^{a}$ Gross energies calculated for hydrated oligomers with waters. ${ }^{b}$ Units number of non hydrogen-bonded water molecules. ${ }^{c}$ Obtained in Table III. dUnits number of hydrogen bonded water molecules.

Table VII. Conformational energy differences $\left(\Delta E_{\mathrm{c}}, \mathrm{kcal} / \mathrm{m} . \mathrm{u} \text {.) }\right)^{\mathrm{a}}$ of El 1- 8-mers (by RHF/6-31G)

\begin{tabular}{|c|c|c|c|c|c|c|c|c|c|c|c|c|c|}
\hline \multirow{2}{*}{$\begin{array}{c}\text { Confor- } \\
\text { mers }\end{array}$} & \multirow[b]{2}{*}{$\mathrm{h}$} & \multirow{2}{*}{$\begin{array}{c}\text { El-1 } \\
N_{w(n)} \\
/ N_{w(h)}\end{array}$} & \multicolumn{3}{|c|}{ El-2 } & \multirow{2}{*}{$\begin{array}{c}\mathrm{El}-3 \\
\mathrm{~N}_{\mathrm{w}(\mathrm{n})} \\
/ \mathrm{N}_{\mathrm{w}(\mathrm{h})}\end{array}$} & \multicolumn{3}{|c|}{ El-4 } & \multirow{2}{*}{$\begin{array}{c}\mathrm{El}-5 \\
\mathrm{~N}_{\mathrm{w}(\mathrm{n})} \\
/ \mathrm{N}_{\mathrm{w}(\mathrm{h})}\end{array}$} & \multicolumn{3}{|c|}{ El-8 } \\
\hline & & & $\Delta E_{\mathrm{c}}$ & $\begin{array}{l}\mathrm{N}_{\mathrm{w}(\mathrm{n})} \\
/ \mathrm{N}_{\mathrm{w}(\mathrm{h})}\end{array}$ & $\Delta E_{\mathrm{c}}$ & & $\Delta E_{\mathrm{c}}$ & $\begin{array}{l}\mathrm{N}_{\mathrm{w}(\mathrm{n})} \\
/ \mathrm{N}_{\mathrm{w}(\mathrm{h})}\end{array}$ & $\Delta E_{\mathrm{c}}$ & & $\Delta E_{\mathrm{c}}$ & $\begin{array}{r}N_{w(n)} \\
/ N_{w(h)}\end{array}$ & $\Delta E_{\mathrm{c}}$ \\
\hline \multirow[t]{3}{*}{$(\mathrm{ttt})_{\mathrm{x}}$} & 0 & $0 / 0$ & $0^{\mathrm{b}}$ & $0 / 0$ & $0^{c}$ & $0 / 0$ & $0^{d}$ & $0 / 0$ & $0^{\mathrm{e}}$ & $0 / 0$ & $0^{f}$ & $0 / 0$ & $0^{g}$ \\
\hline & $0.4-0.7$ & $1 / 0$ & -8.03 & $2 / 0$ & -8.19 & $2 / 0$ & -5.50 & $3 / 0$ & -6.20 & $3 / 0$ & -4.98 & $4 / 0$ & -4.11 \\
\hline & 1 & $2 / 0$ & -17.3 & $3 / 0$ & -12.2 & $4 / 0$ & -11.0 & $5 / 0$ & -10.0 & $6 / 0$ & -10.1 & $9 / 0$ & -9.32 \\
\hline \multirow[t]{3}{*}{$\left(\operatorname{tg}^{+} t\right)_{x}$} & 0 & $0 / 0$ & 0.82 & $0 / 0$ & -1.73 & $0 / 0$ & -1.78 & $0 / 0$ & -1.79 & $0 / 0$ & -1.79 & $0 / 0$ & -1.83 \\
\hline & $0.4-0.7$ & $1 / 0$ & -9.91 & $2 / 0$ & -10.7 & $0 / 2$ & -6.17 & $1 / 2$ & -7.39 & $1 / 2$ & -6.85 & $2 / 2$ & -6.07 \\
\hline & 1 & $2 / 0$ & -21.5 & $1 / 2$ & -12.9 & $0 / 2,2$ & -11.0 & $0 / 5$ & -7.88 & $0 / 6$ & -8.23 & $1 / 8$ & -6.90 \\
\hline \multirow[t]{3}{*}{$\left(\operatorname{tg}^{+} g^{-}\right)_{x}$} & 0 & $0 / 0$ & 1.88 & $0 / 0$ & 1.69 & $0 / 0$ & 1.65 & $0 / 0$ & 1.57 & $0 / 0$ & 1.59 & $0 / 0$ & 1.55 \\
\hline & $0.4-0.7$ & $1 / 0$ & -4.89 & $0 / 2$ & -7.12 & $0 / 2$ & -5.90 & $0 / 3$ & -4.71 & $0 / 3$ & -5.15 & $0 / 4$ & -3.01 \\
\hline & 1 & $2 / 0$ & -13.4 & $1 / 2$ & -10.5 & $0 / 2,2$ & -7.99 & $3 / 2$ & -6.89 & $-^{\mathrm{h}}$ & $-^{\mathrm{h}}$ & $-^{\mathrm{h}}$ & $-^{\mathrm{h}}$ \\
\hline \multirow[t]{3}{*}{$\left(\operatorname{ttg}^{+}\right)_{x}$} & 0 & $0 / 0$ & 0.40 & $0 / 0$ & 0.44 & $0 / 0$ & 0.42 & $0 / 0$ & 0.41 & $0 / 0$ & 0.41 & $0 / 0$ & 0.41 \\
\hline & $0.4-0.7$ & $1 / 0$ & -8.09 & $2 / 0$ & -7.88 & $2 / 0$ & -5.17 & $3 / 0$ & -5.76 & $3 / 0$ & -4.53 & $4 / 0$ & -3.62 \\
\hline & 1 & $2 / 0$ & -16.1 & $1 / 2$ & -10.0 & $2 / 2$ & -9.29 & $3 / 2$ & -8.79 & $4 / 2$ & -8.51 & $3 / 2,2,2$ & -7.25 \\
\hline \multirow[t]{3}{*}{$\left(\operatorname{tg}^{+} g^{+}\right)_{x}$} & 0 & $0 / 0$ & -1.38 & $-i$ & $-i$ & $-i$ & $-i$ & $-i$ & $-i$ & $-i$ & $-i$ & $-^{i}$ & $-i$ \\
\hline & $0.4-0.7$ & $1 / 0$ & -9.41 & $-^{i}$ & $-i$ & $-^{i}$ & $-i$ & $-^{i}$ & $-^{i}$ & $-i$ & $-i$ & $-^{i}$ & $-i$ \\
\hline & 1 & $0 / 2$ & -17.8 & $-i$ & $-i$ & $-i$ & $-i$ & $-i$ & $-i$ & $-i$ & $-i$ & $-i$ & $-i$ \\
\hline \multirow[t]{3}{*}{$\left(g^{+} g^{+} g^{+}\right)_{x}$} & 0 & $一^{j}$ & $-^{\mathrm{j}}$ & $0 / 0$ & 0.88 & $0 / 0$ & 0.71 & $0 / 0$ & 0.55 & $0 / 0$ & 0.45 & $0 / 0$ & 0.25 \\
\hline & $0.4-0.7$ & $-\mathrm{j}$ & $一^{j}$ & $2 / 0$ & -7.09 & $2 / 0$ & -4.73 & $3 / 0$ & -5.40 & $3 / 0$ & -4.44 & $4 / 0$ & -3.97 \\
\hline & 1 & $-\mathrm{j}$ & $-^{\mathrm{j}}$ & $1 / 2$ & -9.10 & $0 / 2,2$ & -8.81 & $1 / 4$ & -8.63 & $0 / 2,4$ & -7.79 & $0 / 4,5$ & -6.77 \\
\hline
\end{tabular}

${ }^{a}$ Calculated based on the energies $\left(E_{\mathrm{c}}\right)$ of $(\mathrm{ttt})_{\mathrm{x}}$ conformers with $\mathrm{h}=0 .{ }^{\mathrm{b}} E_{\mathrm{c}}=-267.2045(\mathrm{HF}) .{ }^{\mathrm{c}} E_{\mathrm{c}}=-400.2294(\mathrm{HF}) .{ }^{\mathrm{d}} E_{\mathrm{c}}=-533.2542(\mathrm{HF})$ ${ }^{\mathrm{e}} E_{\mathrm{c}}=-666.2791(\mathrm{HF}) .{ }^{\mathrm{f}} E_{\mathrm{c}}=-799.3040(\mathrm{HF}) .{ }^{\mathrm{g}} E_{\mathrm{c}}=-1198.3786(\mathrm{HF})$. ${ }^{\mathrm{h}}$ Non-converged in optimization. ${ }^{\mathrm{i}}$ Transferred from the designated (tg+ $\left.{ }^{+}\right)_{\mathrm{x}}$ to the $\left(\operatorname{tg}^{+} \mathrm{g}^{+}\right)_{1}\left(\mathrm{~g}^{+} \mathrm{g}^{+} \mathrm{g}^{+}\right)_{\mathrm{x}-1}$ conformers by optimization in gaseous phase. ${ }^{20}$ iTransferred from the designated $\left(\mathrm{g}^{+} \mathrm{g}^{+} \mathrm{g}^{+}\right)_{1}$ to the $\left(\mathrm{tg}^{+} \mathrm{t}\right)_{1}$ conformer by optimization in gaseous phase. ${ }^{20}$

of energy between the $(\mathrm{ttt})_{\mathrm{x}}$ conformer in non-hydrate states and the other conformers, $\Delta E_{\mathrm{c}}$ (kcal/m.u., m.u.: monomer units), were calculated. The results are shown in Table VII. As shown in Table VII, the calculations for the $\left(\mathrm{g}^{+} \mathrm{g}^{+} \mathrm{g}^{+}\right)_{1}$ and $\left(\operatorname{tg}^{+} \mathrm{g}^{+}\right)_{\mathrm{x}} \quad(\mathrm{x}=2-8)$ conformers could not be carried out because the conformations at non-hydrated states changed from those in the designations to other those in the optimizations (for details, refer footnotes of Table VII). ${ }^{20}$
The hydrate effects on the energy of each conformer were examined. The hydrate energy, $\Delta \mu_{\mathrm{h}}$ ( $\mathrm{kcal} / \mathrm{m} . \mathrm{u}$.), was defined as the difference of the conformational energy $\left(E_{\mathrm{c}}\right)$ of hydrated and non-hydrated oligomer. In Figure 4 , the $\Delta \mu_{\mathrm{h}}$ values (based on the values in non-hydrates) are plotted against the hydrate ratios (h). The plots fell on a straight line with a negative slope and the slope became less steep with increasing values of $\mathrm{x}$. These results indicate that the hydrate 


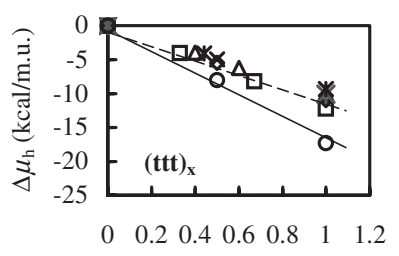

$\mathrm{h}$

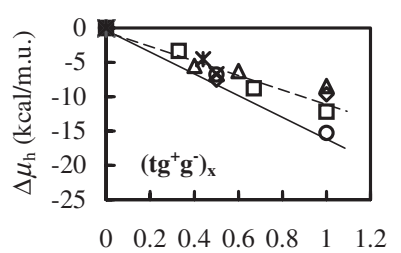

$\mathrm{h}$

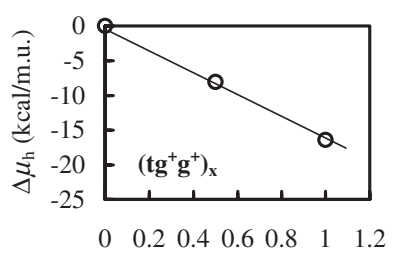

$\mathrm{h}$

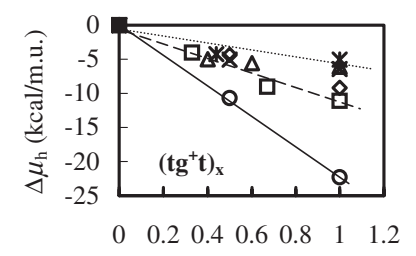

$\mathrm{h}$

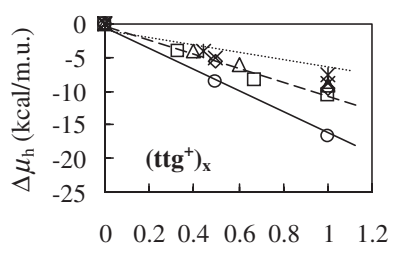

$\mathrm{h}$

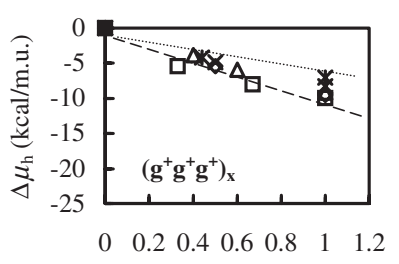

$\mathrm{h}$
Figure 4. Plots of hydrate energies: $\Delta \mu_{\mathrm{h}}$ (kcal/m.u.) against hydrate ratios (h) in El oligomers. $\bigcirc: 1$ mer, $\square: 2$ mer, $\diamond: 3$ mer, $\triangle: 4$ mer $\times$ : 5 mer, $*$ : 8 mer.

effects (by hydrogen bonding, and so on) contribute to the stabilities of the conformers, and such effects are diluted with increasing monomer units. In our previous paper, ${ }^{21}$ in which the conformational analyses for the solutions of EI oligomers (1-4 mers) were carried out by QCC (RHF/ $6-31+\mathrm{G}(\mathrm{d}, \mathrm{p})$ or B3LYP/6-31G(d)//SCRF/IPCM) using the permittivities of solvents (IPCM method $^{22}$ ), the energy of each conformer decreased with increasing values of the permittivities: $\varepsilon$ ( $\varepsilon=0-80.1$ of water), and such effects seemed to relate to the electrostatic interaction with solvents. It can be estimated that the results in present study using hydrate ratios $(\mathrm{h}=0-1)$ are corresponding to the results calculated using the permittivity $(\varepsilon=0-80.1)$, and all conformers are stabilized by electrostatic effect with increases of hydrate ratios.

\section{Hydrate Effects on Trans/Gauche Preferences}

The hydrate effects on the trans/gauche preferences of each conformer were examined.

The gauche preference energy, $\Delta E_{\mathrm{c}(\mathrm{g})}$ (kcal/m.u.), was defined as the difference of $\Delta E_{\mathrm{c}}$ between a given oligomer and the $(\mathrm{ttt})_{\mathrm{x}}$ oligomer. In Figure 5, the $\Delta E_{\mathrm{c}(\mathrm{g})}$ values are plotted against the number of monomer units $(\mathrm{x})$. In the non-hydrate state, the $\left(\operatorname{tg}^{+} t\right)_{x}$ conformers were the most stable except for that of EI-1. This result means that the C-C bond of the EI conformer prefers the gauche conformation (gauche preference) in the non-hydrate state. From an energetic aspect, this result corresponds to the observed result that a non-hydrated linear PEI crystal has a tgt conformation. ${ }^{4}$
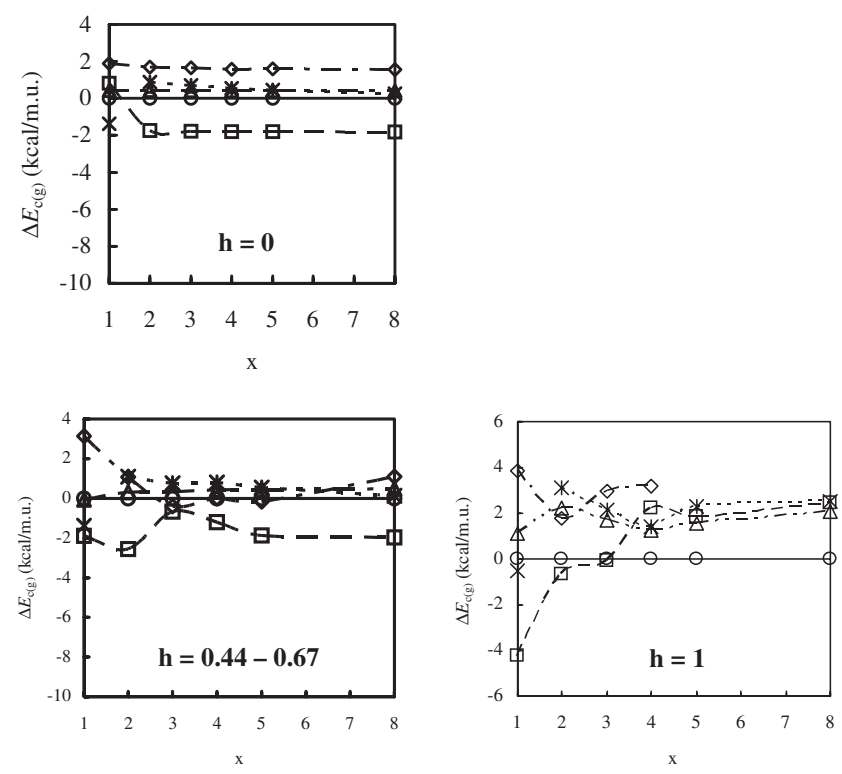

Figure 5. Plots of gauche preference energies $\left(\Delta E_{\mathrm{c}(\mathrm{g})}, \mathrm{kcal} / \mathrm{m} . \mathrm{u}\right.$.) against number of monomer units $(\mathrm{x})$ in El oligomers. $\bigcirc:(\mathrm{ttt})_{\mathrm{x}}, \square:\left(\mathrm{tg}^{+} \mathrm{t}\right)_{\mathrm{x}}$ $\diamond:\left(\operatorname{tg}^{+} \mathrm{g}^{-}\right)_{\mathrm{x}}, \triangle:\left(\operatorname{tgg}^{+}\right)_{\mathrm{x}}, \mathrm{x}:\left(\operatorname{tg}^{+} \mathrm{g}^{+}\right)_{\mathrm{x}}, *:\left(\mathrm{g}^{+} \mathrm{g}^{+} \mathrm{g}^{+}\right)_{\mathrm{x}}$.

As shown in Figure 5, in the hydrate states with h values of $0.44-0.67$, the $\left(\operatorname{tg}^{+} t\right)_{x}$ conformers were the most stable as in the non-hydrate states. In the hydrate states with $\mathrm{h}$ values of 1 , however, the $(\mathrm{ttt})_{\mathrm{x}}$ conformers were the most stable except for those of EI-1 and EI-2. This result in $\mathrm{h}=1$ seems to be related with the formation of hydrogen bond between water molecules neighboring the hydrated conformer. The formation of hydrogen bond between water molecules neighboring the hydrated conformer was confirmed by the $\mathrm{O} \cdots \mathrm{O}$ distance $\left(\mathrm{D}_{\mathrm{O}-\mathrm{O}}\right.$, shorter than $3 \AA$ ) between water molecules as mentioned in calculation section. In all $(\mathrm{ttt})_{\mathrm{x}}$ conformers with $\mathrm{h}=1$, as shown in Figure 2 and Table VII, the water molecules neighboring these hydrated conformers are not in hydrogen bonding network (longer than $3 \AA$ of $\left.\mathrm{D}_{\mathrm{O}-\mathrm{O}}\right)$. In the $(\mathrm{ttt})_{\mathrm{x}}$ conformers, it is considered that the water molecules are far from each other because the paired imino groups are in a racemo structure. On the other hand, in the $\left(\operatorname{tg}^{+} t\right)_{x}$ conformers with $h=1$ except for EI-1, almost water molecules neighboring these hydrated conformers are in hydrogen bonding network (shorter than $3 \AA$ of $\mathrm{D}_{\mathrm{O}-\mathrm{O}}$ ) as shown in Table VII and Figure 6 (structure of hydrated $\left(\operatorname{tg}^{+} t\right)_{2}$ conformer $(E I-2)$ with $h=1$, for example). In the $\left(\operatorname{tg}^{+} t\right)_{x}$ conformers, it can be considered that the water molecules are pulled closer to each other by the inter-molecular interactions with the imino groups having a meso structure, and this results in hydrogen bonding of the water molecules. It was estimated that such formation of hydrogen bond between water molecules causes the increasing of hydrate distance $\left(\mathrm{d}_{\mathrm{N}-\mathrm{H}}\right)$ as in detail mentioned later section (see Figure 6 and Table VIII). Taking into account these results in $\mathrm{h}=1$ mentioned above, the $E_{\mathrm{c}}$ values of the $\left(\operatorname{tg}^{+} \mathrm{t}\right)_{\mathrm{x}}$ conformers with $\mathrm{h}=1$ (over 2 mers) must increase with increasings of the hydrate distances, and the $(\mathrm{ttt})_{\mathrm{x}}$ conformers with $\mathrm{h}=1$ (over 3 mers) were more stabilized by the hydrate effects than the $\left(\operatorname{tg}^{+} t\right)_{x}$ conformers 


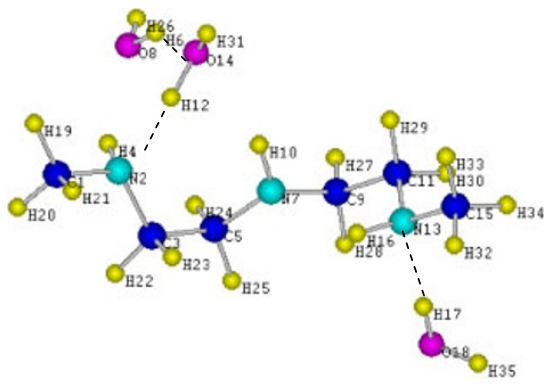

Optimized

$\mathrm{d}_{\mathrm{N}-\mathrm{H}}(\AA)$ : N2-H6 $=2.95, \mathrm{~N} 2-\mathrm{H} 12=1.83$ (H-bond), $\mathrm{N} 7-\mathrm{H} 12=2.93, \mathrm{~N} 13-\mathrm{H} 17=1.94$ (H-bond) $\mathrm{d}_{\mathrm{N}-\mathrm{O}}(\AA): \mathrm{N} 2-\mathrm{O} 8=3.03, \mathrm{~N} 2-\mathrm{O} 14=2.76$ (in H-bonding), $\mathrm{N} 7-\mathrm{O} 14=3.28, \mathrm{~N} 13-\mathrm{O} 18=2.89$ (in H-bonding) $\mathrm{D}_{\mathrm{O}-\mathrm{O}}(\AA)$ : O8-O14 = 2.74 (in H-bonding), O14-O18 = 7.39 $\mathrm{D}_{\mathrm{O}-\mathrm{H}}(\AA): \mathrm{O} 14-\mathrm{H} 6=1.87$ (H-bond)

Figure 6. Structure optimized for the hydrated conformer of El-2 (conformation: $\left(\operatorname{tg}^{+} t\right)_{2}, h=1, \cdots$ : hydrogen bond)

with $\mathrm{h}=1$ as shown in Figure 5. Additionally, the $\Delta E_{\mathrm{c}(\mathrm{g})}$ value of $\left(\operatorname{tg}^{+} \mathrm{t}\right)_{1}$ conformer (EI-1) with $\mathrm{h}=1$ is significantly small as shown in Figure 5. The small $\Delta E_{\mathrm{c}(\mathrm{g})}$ value is ascribed to the fact that the hydrogen bond is not formed between water molecules neighboring the hydrated conformer (see Figure 3 and Table VII).

Sasanuma et al. ${ }^{7}$ has reported that the characteristic ratios $\left(\mathrm{P}_{\text {meso }} / \mathrm{P}_{\text {racemo }}\right)$ of PEI chaines, which were evaluated from energy parameters, changed from $0.63 / 0.37$ in gaseous state to $0.52 / 0.48$ in the state that intra-molecular interaction $(\mathrm{NH} \cdots \mathrm{H})$ was neglected. The results estimated in present study support these evaluated results. The conformation of linear PEI crystal transfers from tgt to ttt with hydration. ${ }^{3-5}$ The results estimated with $\mathrm{h}=1$ in present study showed interesting consistency with the experimental results.

\section{Hydrate Effects on the Structures of Conformers}

The hydrate effects on the conformational structures optimized for EI 1-8 mers were examined. The dihedral angles $\left(\tau_{\mathrm{n}}\right)$ of $\mathrm{C}-\mathrm{C}$ bonds and molecular lengths (l) of each conformer are shown in Tables VIII and IX.

In Table VIII, the hydrate distances, $\mathrm{d}_{\mathrm{N}-\mathrm{H}}(\AA)$, of EI-1 and EI-2 are shown. In the cases that the hydrogen bonding between water molecules neighboring an imino group is not formed, the $\mathrm{d}_{\mathrm{N}-\mathrm{H}}$ values are in $1.9-2.0 \AA$, as evidenced by Figures 2 and 3, and Table VII. On the other hand, in the cases that such hydrogen bonding is formed, the $\mathrm{d}_{\mathrm{N}-\mathrm{H}}$ values become to 2.2-3.6 $\AA$ (subscripting data: "d" in Table VIII), as evidenced by Figure 6 and Table VII. These effects, that the formations of hydrogen bonds between water molecules neighboring imino groups affect the $\mathrm{d}_{\mathrm{N}-\mathrm{H}}$ values, were also estimated in all hydrated conformers over 3 mers. These effects seem to be related with a change of the relative location between the oligomer having meso-type imino groups and the water molecule neighboring the imino groups. For instance, as shown in Figure 6, two water molecules (O8- and O14-) are pulled closer to each other because of the paired imino groups (N2and N7-, meso), and this results in hydrogen bonding of the two water molecules ( $\mathrm{D}_{\mathrm{O}-\mathrm{O}}$ : O8 $\cdots \mathrm{O} 14=2.74 \AA$ ). At the same time, each water molecule is pulled away from the two imino groups $\left(\mathrm{d}_{\mathrm{N}-\mathrm{H}}: \mathrm{N} 2 \cdots \mathrm{H} 6=2.95, \quad \mathrm{~N} 7 \cdots \mathrm{H} 12=2.93 \AA\right)$ except for one counter hydrate $\left(\mathrm{d}_{\mathrm{N}-\mathrm{H}}: \mathrm{N} 2 \cdots \mathrm{H} 12=1.83 \AA\right)$. It can be considered that the formation of hydrogen bond between water molecules results in weakening of the inter-molecular inter-

Table VIII. Structures optimized for El 1- and 2-mers by RHF/6-31G

\begin{tabular}{|c|c|c|c|c|c|c|c|c|c|c|c|}
\hline \multirow{3}{*}{$\begin{array}{c}\text { Confor- } \\
\text { mers }\end{array}$} & \multicolumn{5}{|l|}{ El-1 } & \multicolumn{6}{|l|}{$\mathrm{El}-2$} \\
\hline & \multirow[t]{2}{*}{$\mathrm{h}$} & \multirow[t]{2}{*}{$\tau_{\mathrm{n}}\left({ }^{\circ}\right)^{\mathrm{a}}$} & \multirow[t]{2}{*}{$\begin{array}{c}\mathrm{L} \\
(\stackrel{\mathrm{A}}{\mathrm{b}})^{\mathrm{b}}\end{array}$} & \multicolumn{2}{|c|}{$\begin{array}{c}\text { Hydrate } \\
\text { distances: } \\
\text { d, }(\AA)^{\mathrm{c}}\end{array}$} & \multirow[t]{2}{*}{$\mathrm{h}$} & \multirow[t]{2}{*}{$\begin{array}{c}\boldsymbol{\tau}_{\mathrm{n}}\left({ }^{\circ}\right)^{\mathrm{a}} \\
\text { (average) }\end{array}$} & \multirow[t]{2}{*}{$\begin{array}{c}\mathrm{L} \\
(\stackrel{\AA}{\mathrm{b}})^{\mathrm{b}}\end{array}$} & \multicolumn{2}{|c|}{$\begin{array}{l}\text { Hydrate } \\
\text { d, }(\AA)^{\mathrm{c}}\end{array}$} & \multirow{2}{*}{$\begin{array}{c}\text { distances: } \\
\mathrm{d}_{\mathrm{N}^{\prime \prime}-\mathrm{H}}\end{array}$} \\
\hline & & & & $d_{N-H}$ & $d_{N^{\prime}-H}$ & & & & $d_{N-H}$ & $d_{N^{\prime}-H}$ & \\
\hline \multirow[t]{3}{*}{$(\mathrm{ttt})_{\mathrm{x}}$} & 0 & -180.0 & 3.73 & - & - & 0 & 179.9 & 7.35 & - & - & - \\
\hline & 0.5 & 179.3 & 3.74 & 1.97 & - & 0.67 & 178.7 & 7.36 & 1.97 & - & 1.94 \\
\hline & 1 & 180.0 & 3.75 & 1.93 & 1.92 & 1 & 174.1 & 7.33 & 1.93 & 2.19 & 1.91 \\
\hline \multirow[t]{3}{*}{$\left(\operatorname{tg}^{+} t\right)_{x}$} & 0 & 48.2 & 2.82 & - & - & 0 & 63.0 & 5.56 & - & - & - \\
\hline & 0.5 & 48.2 & 2.82 & 1.90 & - & 0.67 & 66.9 & 5.70 & 1.92 & - & 1.91 \\
\hline & 1 & 52.9 & 2.93 & 1.96 & 1.88 & 1 & 64.7 & 5.60 & $2.95^{d}$ & $2.93^{d}$ & 1.94 \\
\hline \multirow[t]{3}{*}{$\left(\operatorname{tg}^{+} g^{-}\right)_{x}$} & 0 & 76.4 & 3.14 & - & - & 0 & 71.0 & 5.67 & - & - & - \\
\hline & 0.5 & 89.7 & 3.28 & 2.01 & - & 0.67 & 67.1 & 5.40 & $3.61^{d}$ & - & 1.85 \\
\hline & 1 & 89.9 & 3.30 & 2.00 & 1.93 & 1 & 49.4 & 5.38 & $3.56^{d}$ & 1.93 & 1.85 \\
\hline \multirow[t]{3}{*}{$\left(\operatorname{ttg}^{+}\right)_{x}$} & 0 & -177.3 & 3.74 & - & - & 0 & -177.2 & 6.82 & - & - & - \\
\hline & 0.5 & -178.0 & 3.75 & 1.96 & - & 0.67 & -177.6 & 6.75 & 1.95 & - & 1.98 \\
\hline & 1 & -179.6 & 3.76 & 1.95 & 1.96 & 1 & -170.7 & 6.80 & 1.96 & $2.19^{d}$ & 1.94 \\
\hline \multirow[t]{3}{*}{$\left(\operatorname{tg}^{+} g^{+}\right)_{x}$} & 0 & 60.3 & 2.91 & - & - & 0 & - & - & - & - & - \\
\hline & 0.5 & 66.2 & 3.04 & 1.93 & - & 0.67 & - & - & - & - & - \\
\hline & 1 & 54.2 & 2.84 & 1.85 & $3.20^{d}$ & 1 & - & - & - & - & - \\
\hline \multirow[t]{3}{*}{$\left(g^{+} g^{+} g^{+}\right)_{x}$} & 0 & - & - & - & - & 0 & 59.6 & 6.03 & - & - & - \\
\hline & 0.5 & - & - & - & - & 0.67 & 58.2 & 5.97 & 1.97 & - & 1.95 \\
\hline & 1 & - & - & - & - & 1 & 65.5 & 6.15 & 1.98 & $2.13^{d}$ & 1.96 \\
\hline
\end{tabular}

a Dihedral angles of C-C bonds. ${ }^{b}$ Molecular lengths (un-bonded distances between the terminal nitrogen atoms) ${ }^{\mathrm{c}}$ The un-bonded distances between the nitrogen atom $\left(\mathrm{N}, \mathrm{N}^{\prime}\right.$, or $\left.\mathrm{N}^{\prime \prime}\right)$ and the hydrogen atom $(\mathrm{H})$ of water molecule neighboring the nitrogen atom, refer Figures $1-3$, and 6 . d/n these cases, the formation of hydrogen bond (shorter than $3 \AA$ of $D_{0-0}$ ) between water molecules was estimated. Refer Table VII and Figure 6. 
Table IX. Structures optimized for El 3- 5-mers and El-8 mers by RHF/6-31G

\begin{tabular}{|c|c|c|c|c|c|c|c|c|c|c|c|c|}
\hline \multirow{2}{*}{$\begin{array}{c}\text { Confor- } \\
\text { mers }\end{array}$} & \multicolumn{3}{|l|}{ El-3 } & \multicolumn{3}{|l|}{ El-4 } & \multicolumn{2}{|l|}{ El-5 } & \multicolumn{3}{|c|}{ El-8 } & \multirow[b]{2}{*}{$\begin{array}{l}\mathrm{L} \\
(\AA)\end{array}$} \\
\hline & $\mathrm{h}$ & $\tau_{\mathrm{n}}\left({ }^{\circ}\right)$ & $\begin{array}{l}\mathrm{L} \\
(\AA)\end{array}$ & $\mathrm{h}$ & $\tau_{\mathrm{n}}\left({ }^{\circ}\right)$ & $\begin{array}{l}\mathrm{L} \\
(\AA)\end{array}$ & $\mathrm{h}$ & $\tau_{\mathrm{n}}\left({ }^{\circ}\right)$ & $\begin{array}{l}\mathrm{L} \\
(\AA)\end{array}$ & $\mathrm{h}$ & $\tau_{\mathrm{n}}\left({ }^{\circ}\right)$ & \\
\hline \multirow[t]{3}{*}{$(\mathrm{ttt})_{\mathrm{x}}$} & 0 & 179.9 & 11.0 & 0 & 180.0 & 14.7 & 0 & 180.0 & 18.4 & 0 & 180.0 & 29.4 \\
\hline & 0.5 & 178.8 & 11.1 & 0.6 & 178.7 & 14.7 & 0.5 & 179.6 & 18.3 & 0.44 & 179.2 & 29.1 \\
\hline & 1 & 178.7 & 11.1 & 1 & 178.8 & 14.8 & 1 & 179.0 & 18.4 & 1 & 178.9 & 29.5 \\
\hline \multirow[t]{3}{*}{$\left(\operatorname{tg}^{+} t\right)_{x}$} & 0 & 62.9 & 8.12 & 0 & 62.8 & 10.8 & 0 & 62.7 & 13.6 & 0 & 62.6 & 21.6 \\
\hline & 0.5 & 64.3 & 8.19 & 0.6 & 63.8 & 10.9 & 0.5 & 66.5 & 8.66 & 0.44 & 64.6 & 13.2 \\
\hline & 1 & 68.1 & 7.16 & 1 & 63.7 & 8.86 & 1 & 62.3 & 6.99 & 1 & 58.3 & 17.7 \\
\hline \multirow[t]{3}{*}{$\left(\operatorname{tg}^{+} g^{-}\right)_{x}$} & 0 & 69.9 & 8.66 & 0 & 67.4 & 11.5 & 0 & 68.8 & 14.4 & 0 & 68.3 & 22.9 \\
\hline & 0.5 & $100.7^{a}$ & 8.94 & 0.6 & 65.7 & 9.39 & 0.5 & $105.6^{b}$ & 11.8 & 0.44 & $92.2^{\mathrm{c}}$ & 13.4 \\
\hline & 1 & 77.7 & 8.43 & 1 & 83.9 & 11.2 & 1 & $-^{d}$ & $-^{d}$ & 1 & $-^{d}$ & $-^{d}$ \\
\hline \multirow[t]{3}{*}{$\left(\operatorname{ttg}^{+}\right)_{x}$} & 0 & 177.0 & 9.82 & 0 & 177.0 & 13.2 & 0 & 177.0 & 16.5 & 0 & 177.0 & 26.3 \\
\hline & 0.5 & 177.8 & 9.99 & 0.6 & 177.8 & 13.0 & 0.5 & 177.8 & 16.6 & 0.44 & 177.8 & 26.1 \\
\hline & 1 & 172.6 & 9.46 & 1 & 173.4 & 12.4 & 1 & 174.2 & 15.8 & 1 & 171.2 & 24.4 \\
\hline \multirow[t]{3}{*}{$\left(g^{+} g^{+} g^{+}\right)_{x}$} & 0 & 59.7 & 9.00 & 0 & 59.6 & 11.9 & 0 & 59.6 & 14.9 & 0 & 59.4 & 23.7 \\
\hline & 0.5 & 60.2 & 8.96 & 0.6 & 61.1 & 12.1 & 0.5 & 62.0 & 15.1 & 0.44 & 62.3 & 24.1 \\
\hline & 1 & 63.7 & 7.48 & 1 & 59.2 & 10.4 & 1 & 61.4 & 13.3 & 1 & 65.2 & 16.2 \\
\hline
\end{tabular}

${ }^{a}$ Optimized from the $\left(\operatorname{tg}^{+} \mathrm{g}^{-}\right)_{3}$ designated to the $\left(\operatorname{tg}^{+} \mathrm{g}^{-}\right)_{1}\left(\operatorname{tg}^{+} \mathrm{t}\right)_{1}\left(\mathrm{ttg}^{-}\right)_{1}$ conformer. ${ }^{\mathrm{b}}$ Optimized from the $\left(\mathrm{tg}^{+} \mathrm{g}^{-}\right)_{5}$ designated to the $\left(\operatorname{tg}^{+} \mathrm{g}^{-}\right)_{1}\left(\mathrm{tg}^{+} \mathrm{t}\right)_{2}\left(\operatorname{tg} \mathrm{tg}^{-}\right)_{2}$ conformer. ${ }^{C}$ Optimized from the $\left(\mathrm{tg}^{+} \mathrm{g}^{-}\right)_{8}$ designated to the $\left(\mathrm{tg}^{+} \mathrm{g}^{-}\right)_{5}\left(\mathrm{ttg}^{-}\right)_{2}\left(\mathrm{~g}^{-} \mathrm{g}^{+} \mathrm{g}^{-}\right)_{1}$ conformer. ${ }^{\mathrm{d}}$ Non-converged in optimization.

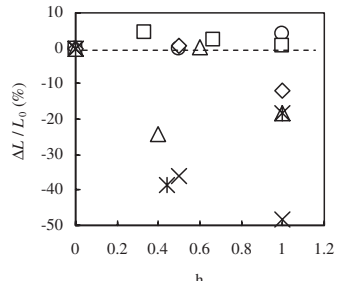

$\left(\operatorname{tg}^{+} t\right)_{x}$

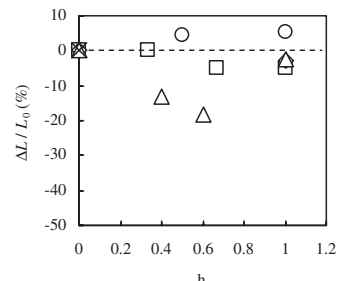

$\left(\operatorname{tg}^{+} \mathbf{g}^{-}\right)_{\mathbf{x}}$

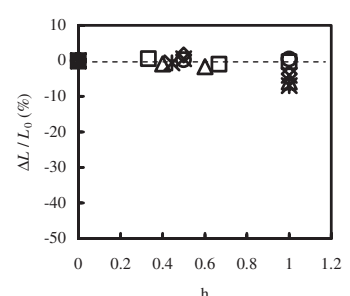

$\left(\operatorname{ttg}^{+}\right)_{x}$

Figure 7. Plots of molecular length's changes: $\Delta L / L_{0}(\%)$ against hydrate ratios (h) in El oligomers. $\bigcirc: 1 \mathrm{mer}, \square: 2 \mathrm{mer}, \diamond: 3 \mathrm{mer}, \triangle: 4 \mathrm{mer}, \mathbf{x}: 5 \mathrm{mer}, *: 8 \mathrm{mer}$.

action between oligomer and water molecule due to the increase of hydrate distance $\left(\mathrm{d}_{\mathrm{N}-\mathrm{H}}\right)$.

One of the structural changes by hydration must be a molecular length due to the changes of $\tau_{\mathrm{n}}$ values. In Figure 7 , the ratios of the change of the length $(\Delta L)$ to the length of the non-hydrated oligomer $\left(L_{0}\right),\left(\Delta L / L_{0}, \%\right)$, in $\left(\operatorname{tg}^{+} \mathrm{t}\right)_{\mathrm{x}},\left(\operatorname{tg}^{+} \mathrm{g}^{-}\right)_{\mathrm{x}}$ and $\left(\operatorname{tgg}^{+}\right)_{\mathrm{x}}$ conformers are plotted against $\mathrm{h}$ values. In Figure 8 , the examples of structures optimized for the hydrated $(\mathrm{ttt})_{8}$ and $\left(\operatorname{tg}^{+} \mathrm{t}\right)_{8}$ conformers (EI-8) with $\mathrm{h}=1$ are shown compared with each non-hydrate conformer. As shown in Figures 7 and 8 , the $\left(\operatorname{tg}^{+} \mathrm{t}\right)_{\mathrm{x}}$ and $\left(\operatorname{tg}^{+} \mathrm{g}^{-}\right)_{\mathrm{x}}$ conformers having higher number of monomer units $(\mathrm{x})$ significantly contracted with increases of $\mathrm{h}$ values, and the $\Delta L / L_{0}$ values of the $\left(\operatorname{tg}^{+} \mathrm{t}\right)_{8}$ and $\left(\operatorname{tg}^{+} \mathrm{g}^{-}\right)_{5}$ conformers were $-39 \%(\mathrm{~h}=0.44)$ and $-18 \%$ $(\mathrm{h}=0.5)$, respectively. On the other hand, the $(\mathrm{ttt})_{\mathrm{x}}$ and $\left(\mathrm{ttg}^{+}\right)_{\mathrm{x}}$ conformers showed only small contractions. These results indicate that the $\mathrm{C}-\mathrm{C}$ bond having gauche structure furthermore contracts by hydration. In Figure 9 , the ratios $\left(\Delta L / L_{0}, \%\right)$ of all conformers except for $(\mathrm{ttt})_{\mathrm{x}}$ are plotted against the gauche preference energies $\left(\Delta E_{\mathrm{c}(\mathrm{g})}\right)$. As shown in Figure 9, many conformers with $\mathrm{h}=1$ are significantly contract compared with those with $\mathrm{h}=0.44-0.67$. However, the values of $\Delta L / L_{0}$ are independent of $\Delta E_{\mathrm{c}(\mathrm{g})}$ in both cases. This result indicates that the contraction of oligomer molecule by hydration is independent of its conformational stability.

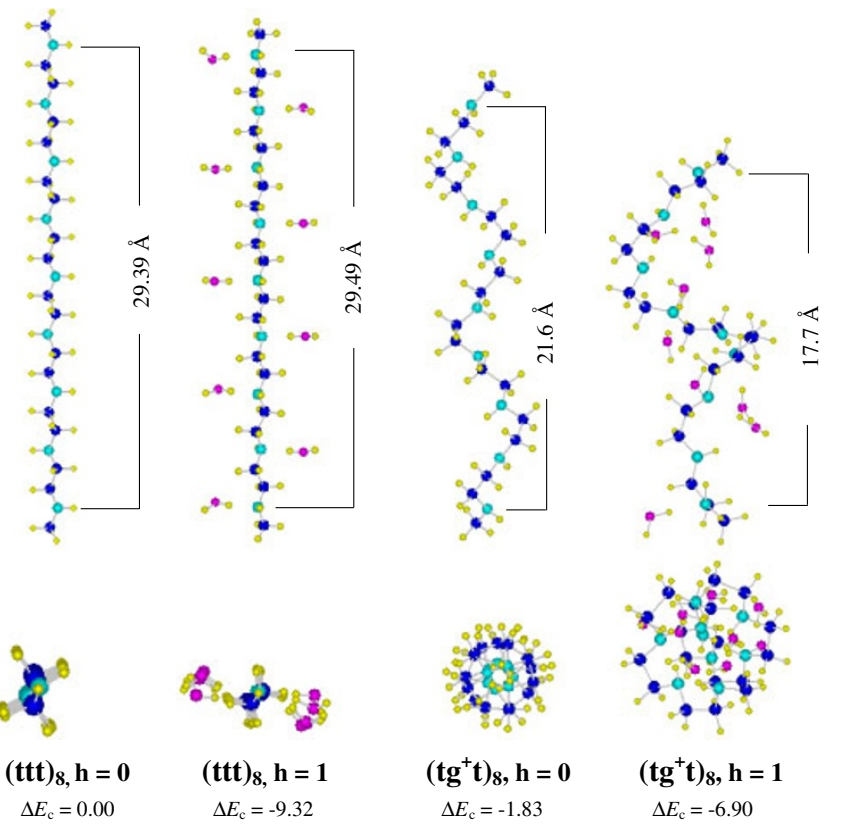

Figure 8. Structures of $(\mathrm{ttt})_{8}$ and $\left(\mathrm{tg}^{+} \mathrm{t}\right)_{8}$ conformers optimized for $\mathrm{El}-8$ by RHF/6-31G. Upper and lower figures show the stereo oblique and chain axis projections, respectively. 

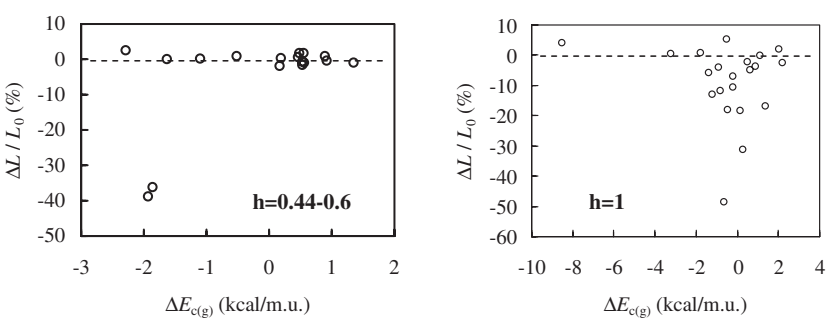

Figure 9. Plots of the rates of changes of molecular lengths $\left(\Delta L / L_{0}, \%\right)$ against gauche preference energies $\left(\Delta E_{\mathrm{c}(\mathrm{g})}, \mathrm{kcal} / \mathrm{m} . \mathrm{u}\right.$.) in hydrated El oligomers (El-1-El-8).

In this study, the hydrate effects on the conformations of EI oligomers were schematically examined by the RHF computation. The investigations using another hydrated models constructed with $\mathrm{h}>1$ or in a double chain, will be available in order to estimate in more detail with the conformations in hydrate state of PEI. We are planning to examine the hydrate effects on the conformations of EI oligomers using more quantitative calculation method such as MP2 with the correction by basis set superposition error (BSSE), ${ }^{28}$ and additionally, using another models such as mentioned above.

\section{CONCLUSION}

Hydrate effects on the conformations of ethylene imine oligomers were schematically examined using the RHF calculation method. Hydrate energies $\left(\Delta \mu_{\mathrm{h}}\right)$ estimated from conformational energy $\left(E_{\mathrm{c}}\right)$ for each conformer were negative and linearly decreased with the increase of hydrate ratios (h), and all conformers were stabilized by hydrations. In partially hydrated states $(\mathrm{h}<1)$, all $\left(\operatorname{tg}^{+} \mathrm{t}\right)_{\mathrm{x}}$ conformers were the most stable as in non-hydrate states. In perfectly hydrated states $(\mathrm{h}=1)$, however, the $(\mathrm{ttt})_{\mathrm{x}}$ conformers (over 3 mers) were the most stable. This result in $\mathrm{h}=1$ seemed to be related with the formation of hydrogen bond between water molecules neighboring an imino group. The hydrated $(\mathrm{ttt})_{\mathrm{x}}$ conformers having a racemo structure were more stabilized than the hydrated $\left(\operatorname{tg}^{+} t\right)_{\mathrm{x}}$ conformers having a meso structure, due to the non-formation of such hydrogen bond between water molecules. These results corresponded to results observed for non-hydrated and hydrated linear PEI crystals. Molecular lengths of conformers having gauche C-C bonds significantly decreased with increases of hydrate ratios. Such contraction by hydration, however, was independent of its conformational stability.
Received: May 12, 2009

Accepted: July 5, 2009

Published: August 19, 2009

\section{REFERENCES}

1. C. S. Harris, M. A. Ratner, and D. F. Shriver, Macromolecules, 20 , 1778 (1987).

2. A. Akinc, D. M. Lynn, D. G. Anderson, and R. Langer, J. Am. Chem. Soc., 125, 5316 (2003).

3. Y. Chatani, H. Tadokoro, T. Saegusa, and H. Ikeda, Macromolecules, 14, 315 (1981)

4. Y. Chatani, T. Kobatake, H. Tadokoro, and R. Tanaka, Macromolecules, 15, 170 (1982).

5. Y. Chatani, T. Kobatake, and H. Tadokoro, Macromolecules, 16, 199 (1983).

6. T. Hashida, K. Tashiro, S. Aoshima, and Y. Inaki, Macromolecules, 35, 4330 (2002).

7. Y. Sasanuma, S. Hattori, S. Imazu, S. Ikeda, T. Kaizuka, T. Iijima, M. Sawanobori, M. A. Azam, R. V. Law, and J. H. G. Steinke, Macromolecules, 37, 9169 (2004).

8. J. E. Mark and P. J. Flory, J. Am. Chem. Soc., 87, 1415 (1965).

9. J. E. Mark and P. J. Flory, J. Am. Chem. Soc., 87, 3702 (1966).

10. G. Geun and J. Breitkreutz, Pharmazie, 49, 562 (1994).

11. H. Dong, J. K. Hyun, C. Durham, and R. A. Wheeler, Polymer, 42, 7809 (2001).

12. S. Wang, L. DeBolt, and J. E. Mark, Polym. Prepr. (Am. Chem. Soc., Div. Polym. Chem.), 34, 478 (1993).

13. Y. Sasanuma, H. Ohta, I. Touma, H. Matoba, Y. Hayashi, and A. Kaito, Macromolecules, 35, 3748 (2002).

14. S. Tsuzuki, T. Uchimaru, K. Tanabe, and T. Hirano, J. Phys. Chem., 97, 1346 (1993).

15. R. L. Jaffe, G. D. Smith, and D. Y. Yoon, J. Phys. Chem., 97, 12745 (1993).

16. G. D. Smith, D. Y. Yoon, and R. L. Jaffe, Macromolecules, 26, 5213 (1993).

17. Y. Sasanuma and K. Sugita, Polym. J., 38, 983 (2006).

18. S. E. Boesch, S. S. York, R. Frech, and R. A. Wheeler, Phys. Chem. Commun., 4, 1 (2001).

19. G. D. Smith, O. Borodin, and D. Bedrov, J. Comput. Chem., 23, 1480 (2002).

20. M. Kobayashi and H. Sato, Polym. J., 40, 343 (2008).

21. M. Kobayashi and H. Sato, Polym. Bull., 61, 529 (2008).

22. J. B. Foresman, T. A. Keith, K. B. Wiberg, J. Snoonian, and M. J. Frisch, J. Phys. Chem., 100, 16098 (1996).

23. "Gaussian 03 User's Reference" Gaussian Inc PA USA, 2003.

24. R. Ludwig, Angew. Chem., Int. Ed., 40, 1808 (2001).

25. T. R. Dyke, K. M. Mack, and J. S. Muenter, J. Chem. Phys., 66, 498 (1977).

26. J. A. Odutola and T. R. Dyke, J. Chem. Phys., 72, 5062 (1980).

27. D. R. Lide, "CRC Handbook of Chemistry and Physics," 82nd ed., CRC Press LLC London, 2001, pp 8-127.

28. S. F. Boys and F. Bernardi, Mol. Phys., 19, 553 (1970). 